\title{
The role of peripheral benzodiazepine receptors on the function and survival of isolated human pancreatic islets
}

Lorella Marselli, Letizia Trincavelli ${ }^{1}$, Carmela Santangelo ${ }^{4}$, Roberto Lupi, Silvia Del Guerra, Ugo Boggi ${ }^{2}$, Alessandra Falleni ${ }^{3}$, Vittorio Gremigni ${ }^{3}$, Franco Mosca ${ }^{2}$, Claudia Martini ${ }^{1}$, Francesco Dotta ${ }^{4}$, Umberto Di Mario ${ }^{4}$, Stefano Del Prato and Piero Marchetti

Dipartimento di Endocrinologia e Metabolismo, Sezione Metabolismo, Università di Pisa, ${ }^{1}$ Dipartimento di Psichiatria, Neurobiologia, Farmacologia e Biotecnologie, Università di Pisa, ${ }^{2}$ Dipartimento di Oncologia, Università di Pisa and ${ }^{3}$ Dipartimento di Morfologia Umana e Biologia Applicata, Università di Pisa, via Paradisa 2, Ospedale Cisanello, 56100 Pisa, Italy and ${ }^{4}$ Dipartimento di Scienze Cliniche, Università La Sapienza, Roma, Italy

(Correspondence should be addressed to P Marchetti; Email: marchant@immr.med.unipi.it)

\begin{abstract}
Objective: Peripheral benzodiazepine receptors (PBRs) are part of the mitochondrial permeability transition pore, and their activation may induce cell death. PBRs are expressed in human pancreatic islets, and cytokine-induced damage is accompanied by changes in their properties. We hypothesized that PBRs can have a role in human islet physiopathology, and evaluated the effects of prolonged exposure to two specific PBR ligands, PK11195 and Ro5-4864 on the function and survival of isolated human islets.

Design: Isolated human islets were prepared from the pancreas of 25 multiorgan cadaveric donors and incubated for $12 \mathrm{~h}$ in the presence of PK11195 or Ro5-4864. Insulin secretion studies and apoptosis experiments were then performed, together with assessment of intracellular pathways involved in islet cell function and survival.

Methods: Islets were prepared by enzymatic digestion and density gradient purification. Insulin secretion was assessed by the batch incubation method, and glucose oxidation was evaluated by the use of $\mathrm{D}-\left[\mathrm{U}_{-}{ }^{14} \mathrm{C}\right] \mathrm{glucose}$. Apoptosis was studied using the TUNEL technique, ELISA methods, and electron microscopy evaluation. PCR experiments were performed by the use of specific primers. Results: Glucose-stimulated insulin release was significantly lower after exposure to PK11195 than after exposure to Ro5-4864. This was accompanied by reduced glucose oxidation and no major change of insulin or GLUT-1 mRNA expression. Apoptosis was higher in PK11195-exposed islets, and electron microscopy demonstrated the involvement of beta-cells. The apoptotic effects were prevented by bongkrekic acid and low-dose cyclosporin A, which stabilize the mitochondrial membrane, and were associated with no evident change of inducible nitric oxide synthase (iNOS), B-cell leukemia/lymphoma-2 (Bcl-2) or Bcl-2-associated X protein (Bax) expression. Caspase inhibition markedly reduced the amount of apoptosis, and the role of these proteases was confirmed by the increased activity of caspase- 3 and caspase- 9 .

Conclusions: Prolonged binding to PBRs may cause human beta-cells functional damage and apoptosis, a phenomenon which is prevented by stabilizing the mitochondrial membrane; occurs without changes of iNOS, Bax and Bcl-2 mRNA expression; and involves caspase activation. These results suggest an involvement of PBRs in human pancreatic beta-cell function and survival.
\end{abstract}

European Journal of Endocrinology $151207-214$

\section{Introduction}

Peripheral benzodiazepine receptors (PBRs) are heteromeric complexes, not linked to the GABA/chloride ion channel macromolecules, derived from the interaction of a number of components; they consist of an isoquinoline binding protein of $18 \mathrm{kDa}$ molecular weight (pk-18), a voltage-dependent anion channel (VDAC), and an adenine nucleotide translocator (ANT) (1). The PBR complex has been described as being located at the contact site between the outer and the inner mitochondrial membranes. Its subunit composition is thought to coincide with that of the mitochondrial permeability transition pore (PTP), which opens under specific conditions and enables unselective passage of molecules between the mitochondrial matrix and the cytoplasm $(2,3)$.

To study the function of PBRs, several ligands have been used. The most commonly employed are 1-(2chlorophenyl)-N-methyl- $N$-(1-methylpropyl)-3-isoquinolonecarboxamide (PK11195), an isoquinoline carboxamide, and Ro5-4864, a diazepam derivative. 
PK11195 binds specifically and selectively to the pk-18 protein, whereas Ro5-4864 binds to the whole PBR protein complex (pk-18 protein, VDAC and ANT). By the use of PK11195 and/or Ro5-4864 it has been demonstrated that PBRs are present in most human tissues and are involved in the function of several cell types (including human pancreatic islet cells), where they play a well-defined role in some hormonal and immunological functions $(4-6)$.

Recently, much attention has been directed towards PBRs because of their possible role in events leading to cell death. Chelli et al. (7) have demonstrated that PBR ligands induce a dose-dependent and cyclosporin A-sensitive increase of mitochondrial permeability transition, together with mitochondrial ultrastructural alterations. PK11195 has been shown to facilitate the induction of apoptosis in a number of hematopoietic cell lines exposed to glucocorticoid receptor agonists, chemotherapeutic agents or gamma irradiation $(8-10)$, and to reverse the Bcl-2 cytoprotective effect obtained by its transfection-enforced overexpression. In addition, PK11195 can induce apoptosis in murine thymocytes (11). Conversely, it has been reported that Ro5-4864 might exert an anti-apoptotic function, as suggested by its protective effects on human lymphoblastoid cell line U937 exposed to pro-apoptotic stimuli, such as tumor necrosis factor alpha (12). More recently, we have reported that PBR expression and density in human islets is increased after cytotoxic cytokines treatment, suggesting a possible involvement of these receptors in the mechanisms leading to betacell death in response to inflammatory damage (13).

To explore the role of PBRs in human islets, we decided to investigate whether prolonged exposure to specific PBRs ligands might affect the function and survival of human pancreatic islet cells, and to investigate some of the possible mechanisms. The results show that binding of PK11195, but not of Ro5-4864, to PBRs, causes human beta cells functional damage and apoptosis. This latter phenomen is prevented by stabilizing the mitochondrial permeability pore, occurs without any significant change of inducible nitric oxide synthase (iNOS), Bax and Bcl-2 mRNA expression, and involves the activation of several caspases.

\section{Materials and methods}

\section{Human islet preparation}

Human islets were isolated from the pancreas of 25 multiorgan cadaveric donors and were prepared and characterized as previously described (14). The enzyme collagenase (Collagenase P; Roche) was used for digestion of the pancreas. The pancreatic duct was cannulated and the digestion solution (collagenase, $1.5-2.0 \mathrm{mg} / \mathrm{ml}$, dissolved in $300 \mathrm{ml}$ Hanks' balanced salt solution (HBSS; Sigma) was slowly injected to distend the tissue. The collagenase solution injected was approximately three times (in volume) the weight of the pancreas. After distension, the gland was placed into a $500 \mathrm{ml}$ glass beaker, and the digestion solution not used for distension was added into the beaker. This was loaded into a shaking water bath at $37^{\circ} \mathrm{C}$, activated at 120 r.p.m. After $10 \mathrm{~min}$, the pancreas was shaken with forceps for $60 \mathrm{~s}$; then, the digestate was filtered through 300 and $90 \mu \mathrm{m}$ mesh stainless steel filters, in sequence. The solution that passed through the filters and the tissue entrapped on the $300 \mu \mathrm{m}$ mesh filter were placed back into the water bath, for further digestion. The tissue remaining on the $90 \mu \mathrm{m}$ mesh filter was washed with HBSS and $10 \%$ bovine serum. The same procedures of filtration, washing and settling in the HBSS solution were repeated every $8-10 \mathrm{~min}$ up to $40-50 \mathrm{~min}$.

For the purification procedure, $3 \mathrm{ml}$ tissue were loaded into $250 \mathrm{ml}$ plastic conicals and resuspended in $50 \mathrm{ml}$ of $80 \%$ Histopaque 1.077 (Sigma) and 20\% HBSS, topped with $40 \mathrm{ml}$ HBSS. After centrifugation at $800 \boldsymbol{g}$ for $5 \mathrm{~min}$ at $4^{\circ} \mathrm{C}$, the islets were recovered at the interface between the Histopaque and the HBSS layers. The islets were washed with HBSS by centrifugation at $800 \mathrm{~g}$ for $2 \mathrm{~min}$ at $4^{\circ} \mathrm{C}$, resuspended in M199 culture medium (supplemented with 10\% serum and antibiotics) and cultured at $37^{\circ} \mathrm{C}$ in a $\mathrm{CO}_{2}$ incubator.

\section{Incubation with selective PBR ligands, PK11195 and Ro5-4864}

Purified islets were handpicked and cultured free-floating for $12 \mathrm{~h}$ in M199 culture medium under the following conditions: (a) control M199 medium; (b) M199 medium containing either 0.5 or $1.0 \mu \mathrm{mol} / \mathrm{l}$ PK11195 (Alexis Biochemicals, San Diego, CA, USA); (c) M199 medium containing either 1.0 or $10 \mu \mathrm{mol} / \mathrm{l}$ Ro5-4864 (Fluka Chemie AG, Switzerland); (d) M199 medium containing $1.0 \mu \mathrm{mol} / \mathrm{l}$ PK1 1195 and $10 \mu \mathrm{mol} / \mathrm{l}$ Ro5-4864; (e) M199 medium containing $600 \mu \mathrm{mol} / \mathrm{l}$ clonazepam (Sigma-Aldrich), a specific ligand of central benzodiazepine receptors, that does not bind to the peripheral receptor type (15). PK11195 and Ro5-4864 concentrations used in the present study were consistent with those previously employed with other cell types $(7-12,15)$.

\section{Glucose-stimulated insulin release}

After $12 \mathrm{~h}$ incubation, islet glucose-stimulated insulin secretion was determined as previously described (14, 16). Briefly, following a $45 \mathrm{~min}$ pre-incubation period at $3.3 \mathrm{mmol} / \mathrm{l}$ glucose, batches of approximately 50 islets of comparable size were kept at $37^{\circ} \mathrm{C}$ for $45 \mathrm{~min}$ in Krebs-Ringer bicarbonate solution (KRB), $0.5 \%$ albumin, $\mathrm{pH} 7.4$, containing $3.3 \mathrm{mmol} / \mathrm{l}$ glucose. At the end of this period, the medium was completely removed and replaced with KRB containing 
$16.7 \mathrm{mmol} / \mathrm{l}$ glucose. After an additional $45 \mathrm{~min}$ incubation, the medium was removed. Samples $(500 \mu \mathrm{l})$ from the different media were stored at $-20^{\circ} \mathrm{C}$ until insulin concentrations were measured by immunoradiometric assay (IRMA; Pantec Forniture Biomediche, Turin, Italy).

\section{Glucose oxidation studies}

Glucose oxidation was assessed based on methods previously developed and tested (17). Groups of 15 islets were incubated in a plastic cup in $100 \mu \mathrm{l}$ KRB containing $3 \mu \mathrm{Ci} \mathrm{D}$-[U- $\left.{ }^{14} \mathrm{C}\right]$ glucose plus nonradioactive glucose. The cups, which were suspended in standard $20 \mathrm{ml}$ glass scintillation vials, were gassed with $\mathrm{O}_{2}: \mathrm{CO}_{2}(95 \%: 5 \%)$ and were capped airtight. The vials were then shaken continuously at $37^{\circ} \mathrm{C}$ for $120 \mathrm{~min}$. Islet metabolism was stopped by injecting $100 \mu \mathrm{l}$ $0.05 \mathrm{mmol} / \mathrm{l}$ antimycin A (dissolved in $70 \%$ ethanol) into the cup. This was immediately followed by an injection of $20 \mu \mathrm{l}$ hyamine hydroxide (Sigma) into the vials. ${ }^{14} \mathrm{CO}_{2}$ was liberated from the incubation medium by a subsequent injection into the cup of $100 \mu \mathrm{l} 0.4 \mathrm{mmol} / \mathrm{l} \mathrm{Na}_{2} \mathrm{HPO}_{4}$ solution adjusted to a $\mathrm{pH}$ of 6.0. After $2 \mathrm{~h}$ at room temperature (to allow the liberated ${ }^{14} \mathrm{CO}_{2}$ to be trapped by the hyamine hydroxide), the cup was removed, and $10 \mathrm{ml}$ of a scintillation fluid was added to each vial. Radioactivity was measured in a liquid scintillation counter.

\section{Evaluation of islet cell death}

Islet cell death/survival was assessed by the TUNEL technique (In Situ Cell Death Detection system, Roche) and the Cell Death Detection ELISAplus assay (Roche), both handled according to the procedures recommended by the manufacturer, and applied to human islet experiments (18).

For the TUNEL technique, approximately 50 handpicked islets were dissociated into single cells and fixed on glass slides by paraformaldehyde. After inhibition of endogenous peroxidase and membrane permeabilization, islet cells were exposed to terminal deoxynucleotidyl transferase and fluorescein-labelled nucleotides for $60 \mathrm{~min}$ at $37^{\circ} \mathrm{C}$. Then the slides were treated with an anti-fluorescein antibody conjugated with horse-radish peroxidase (POD), followed by exposure to 3,3'-diaminobenzidine (DAB) substrate. The preparations were finally observed on a light microscope, and dead cells were counted based on nuclear staining.

For the ELISA method aliquots of approximately 15 islets of comparable size were incubated for $30 \mathrm{~min}$ with a lysis buffer at room temperature and then centrifuged at $200 \mathrm{~g}$ for $10 \mathrm{~min}$ at $4^{\circ} \mathrm{C}$. Aliquots of the supernatant $(20 \mu \mathrm{l})$ were placed into microtiter plate wells, coated with streptavidin; $80 \mu \mathrm{l}$ of a mixture containing anti-histone-biotin antibody and anti-DNA-POD antibody were then added, and incubation was allowed for $120 \mathrm{~min}$ at room temperature. The preparations were then washed and $100 \mu \mathrm{l}$ of a solution containing ABTS (the substrate for POD) were added. At the end of $15 \mathrm{~min}$ incubation, absorbance of samples was read spectrophotometrically at $405 \mathrm{~nm}$.

Electron microscopy studies were performed as previously described (18). Human islets were pelleted by centrifugation at $1300 \mathrm{~g}$ and fixed with $2.5 \%$ glutaraldehyde in $0.1 \mathrm{M}$ cacodylate buffer, $\mathrm{pH} 7.4$ for $1 \mathrm{~h}$ at $4{ }^{\circ} \mathrm{C}$. After rinsing in cacodylate buffer, islet pellets were postfixed in 1\% cacodylate-buffered osmium tetroxide for $2 \mathrm{~h}$ at room temperature, then dehydrated in a graded series of ethanol, briefly transferred to propylene oxide and embedded in Epon-Araldite. Ultrathin sections (60-80 nm thick) were cut with a diamond knife, placed on formvar-carbon-coated copper grids (200 mesh), and stained with uranyl acetate and lead citrate.

\section{Effect of mitochondrial PTP inhibition}

Bongkrekic acid (BA, a ligand of ANT) and cyclosporine A (CsA, a ligand of mitochondrial matrix cyclophilin D), are compounds able to inhibit the mitochondrial PTP (19). The effects of BA and CsA on PK11195-induced phenomena were assessed by adding either $50 \mu \mathrm{mol} / \mathrm{l}$ BA (Calbiochem, La Jolla, CA, USA) or $100 \mathrm{ng} / \mathrm{ml}$ CsA to human islets exposed to $1.0 \mu \mathrm{mol} / \mathrm{l} \mathrm{PK} 11195$.

\section{Effects of caspase inhibition}

Several caspase inhibitors can be employed to assess whether and at which level these apoptosis executioners are involved $(20-22)$. For the purpose of the present study we used: DEVD-FMK (Chemicon International, Temecula, CA, USA), which is supposed to inhibit both initiator (upstream) and effector (downstream) caspases (in particular caspase-8, and caspase-3 and -7) and VAD-FMK (Chemicon), which is supposed to inhibit mainly initiator caspases (in particular caspase-8 and -9). The concentrations added into the human islet batches exposed for $12 \mathrm{~h}$ to $1.0 \mu \mathrm{mol} / \mathrm{l}$ PK11195 were $10 \mu \mathrm{mol} / \mathrm{l}$ DEVD-FMK or $10 \mu \mathrm{mol} / \mathrm{l}$ VAD-FMK.

\section{Evaluation of caspase-3 and -9 activity}

Caspase-3 and -9 activity was determined using the Caspase- 3 colorimetric protease assay kit and the Caspase-9 colorimetric protease assay kit (Chemicon) respectively. Batches (700 islets) of control and 1.0 $\mu \mathrm{mol} / \mathrm{l}$ PK11195-treated pancreatic islets were washed twice in cold PBS, resuspended in $50 \mu \mathrm{l}$ cell lysis buffer, and incubated in ice for $10 \mathrm{~min}$. Cell lysates were pelleted by centrifugation at $10000 \mathrm{~g}$ for $1 \mathrm{~min}$, and the supernatants were transferred to fresh tubes. The protein content of the supernatants was measured 
by the Lowry method, and then $150 \mu \mathrm{g}$ protein, diluted to a volume of $50 \mu \mathrm{l}$ with cell lysis buffer, were placed into a microtiter plate well. Fifty microliters of $2 \times$ reaction buffer with $10 \mathrm{mmol} / \mathrm{l}$ dithiothreitol and $5 \mu \mathrm{l}$ of the $4 \mathrm{mmol} / \mathrm{l}$ DEVD-p-nitroanilide substrate or $4 \mathrm{mmol} / \mathrm{l}$ LEHD-p-nitroanilide substrate were added to each well, followed by $2 \mathrm{~h}$ incubation at $37^{\circ} \mathrm{C}$. Optical density (OD) for each specimen was determined spectrophotometrically at $405 \mathrm{~nm}$.

\section{PCR experiments}

Expression of insulin, GLUT-1, iNOS, Bcl-2 and Bax mRNA was assessed by RT-PCR, as previously reported $(18,23-26)$. In particular, human insulin primer pair (5'-GCC TTT GTG AAC CAA CAC CTG-3' and 5'-GTT GCA GTA GTT CTC CAG CTG-3') and GLUT-1 primer pair (5'-TCC ACG AGC ATC TTC GAG A-3' and 5'ATA CTG GAA GCA CAT GCC C-3') generated a 261 and $392 \mathrm{bp}$ product respectively. Human Bcl-2 primer pair (5'-ACA ACA TCG CCC TGT GGA TGA C-3' and 5'-ATA GCT GAT TCG ACG TTT TGC C-3') and Bax primer pair (5'-GGC CCA CCA GCT CTG AGC AGA-3' and 5'-GCC ACG TGG GCG TCC CAA AGT-3') generated a 408 and $477 \mathrm{bp}$ product respectively. Expression of beta-actin as mRNA control was analyzed as previously described $(18,23)$.

\section{Nitrite determination}

Nitrites, the stable end product of NO, were determined (23) in culture medium by incubating 150 islets in $0.6 \mathrm{ml}$ culture medium for $12 \mathrm{~h}$. Triplicate samples of $90 \mu \mathrm{l}$ were then removed from the medium and added to $10 \mu$ freshly prepared solution of $0.5 \% \mathrm{~N}$-(1-naphtyl)ethylendiamine dihydrochloride (NED), $5 \%$ sulphanilamide in a $25 \% \mathrm{H}_{3} \mathrm{PO}_{4}$ solution. The reaction was carried out at $60{ }^{\circ} \mathrm{C}$ for $2 \mathrm{~min}$, and the absorbance at $560 \mathrm{~nm}$ was measured against a standard curve.

\section{Statistical analysis}

Data are given as mean \pm S.D. The ELISA experiment results are expressed as arbitrary units of OD. Statistical analysis was performed using Student's t-test or an ANOVA test, followed by Bonferroni correction, as needed.

\section{Results}

\section{Effects of PBR ligands on islet function}

Basal (3.3 mmol/l glucose) insulin release from control islets was $0.08 \pm 0.03 \mu \mathrm{U} /$ islet per min. It decreased significantly after incubation with $1.0 \mu \mathrm{mol} / \mathrm{l}$ PK11195 $(0.03 \pm 0.01 \mu \mathrm{U} /$ islet per $\min , P<0.05$ vs controls $)$, but was not significantly affected by the presence of $0.5 \mu \mathrm{mol} / \mathrm{l}$ PK11195, 1.0 or $10 \mu \mathrm{mol} / \mathrm{l}$ Ro5-4864, $1.0 \mu \mathrm{mol} / \mathrm{l}$ PK11195 plus $10 \mu \mathrm{mol} / \mathrm{l}$ Ro5-4864, or $600 \mu \mathrm{mol} / \mathrm{l}$ clonazepam, a specific ligand of central benzodiazepine receptors (not shown). As depicted in Fig. 1, PK11195 exhibited an inhibitory effect on glucose-stimulated $(16.7 \mathrm{mmol} / \mathrm{l})$ insulin release at both 0.5 and $1.0 \mu \mathrm{mol} / \mathrm{l}$. Ro5-4864 had no effect on insulin release, nor could it prevent the inhibitory effect of PK11195 (Fig. 1). Incubation of human islets with clonazepam, a specific ligand of central benzodiazepine receptor, did not affect insulin release (Fig. 1). The inhibitory effect of PK11195 on glucose-stimulated insulin release was accompanied by a reduction of glucose oxidation (expressed as pmol/islet per $120 \mathrm{~min}$ ), which was $16.5 \pm 2.8$ and $39.1 \pm 7.4$ (respectively at 3.3 and $16.7 \mathrm{mmol} / \mathrm{l}$ glucose) in control islets, and $12.6 \pm 3.4$ and $17.9 \pm 4.4(P<0.05$ vs controls $)$ in PK11195-exposed islets. However, the results obtained by PCR and the use of specific primers for insulin and GLUT-1 showed that cells pre-incubated with PK11195 exhibited no major change of insulin or GLUT-1 mRNA expression, as compared with control islets (not shown).

Insulin secretion $(\mu \mathrm{U} / \mathrm{islet} / \mathrm{min})$

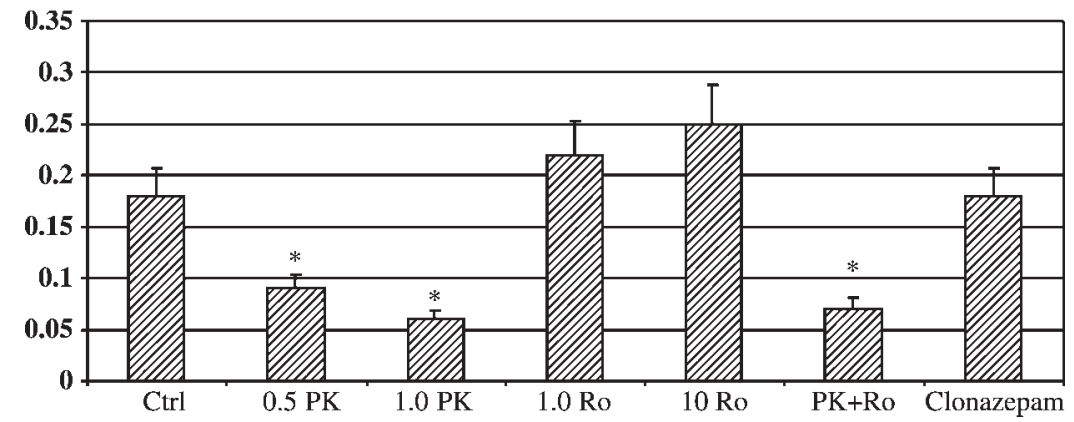

Figure 1 Insulin secretion in response to $16.7 \mathrm{mmol} / /$ glucose from control islets (Ctrl) and islets exposed for $12 \mathrm{~h}$ to $0.5 \mathrm{or} 1.0 \mu \mathrm{mol} / /$ PK11195 (0.5 and 1.0 PK), 1.0 or $10 \mu \mathrm{mol} / / \mathrm{Ro5}-4864$ (1.0 and $10 \mathrm{Ro}$ ), a combination of 1.0 and $10 \mu \mathrm{mol} / \mathrm{l} \mathrm{PK11195}$ and Ro5-4864 (PK $+\mathrm{Ro}$ ) or $600 \mu \mathrm{mol} / /$ clonazepam (Clon). ${ }^{\star} P<0.05$ vs control by the Bonferroni test. 


\section{Effects of PBR ligands on islet cell death}

The amount of islet cell death was determined by the TUNEL technique and an ELISA method. As shown in Table 1, with both procedures the amount of dead cells was higher in human islets exposed to $1.0 \mu \mathrm{mol} / \mathrm{l}$ PK11195, as compared with control islets, Ro5-4864- or clonazepam-exposed cells. When Ro54864 was added to PK11195, the amount of cell death did not differ from that of control islets (Table 1).

Electron microscopy was performed on control islets and islets exposed to PK11195. Typical apoptotic alterations (chromatin condensation, blebs, apoptotic bodies) were apparent in beta-cells of islets pre-exposed to PK11195 (Fig. 2).

\section{Effects of mitochondrial PTP inhibition}

Bongkrekic acid (BA, $50 \mu \mathrm{mol} / \mathrm{l}$ ), a ligand of ANT, or CsA $(100 \mathrm{ng} / \mathrm{ml})$ were used to test whether stabilizing the mitochondrial membrane could change the susceptibility of islet cells to PK11195-induced death (Fig. 3, five separate experiments). The presence of BA significantly reduced the amount of dead cells due to PK11195 exposure (OD from $2.1 \pm 0.5$ to $1.1 \pm 0.5$, $P<0.05)$. When CsA was added to PK11195-containing medium, the amount of cell death (OD 1.7 \pm 0.3 ) did not differ significantly from that of control islets (OD $1.2 \pm 0.4)$.

\section{Effects of PK11195 on some cellular mediators of apoptosis}

When the effects of inhibiting upstream and downstream caspases on PK11195-induced cell death were determined, the results shown in Fig. 4 were obtained. With both VAD-FMK and DEVD-FMK a marked decrease of the amount of cell death (as measured by an ELISA method) was observed. In agreement with this finding, the activity of caspase-3 (OD, $0.19 \pm 0.02$ vs $0.12 \pm 0.03 ; n=5, P<0.05)$ and caspase-9 (OD,

Table 1 Amount of dead islet cells (mean士S.D.) in control islets and islets exposed to $1.0 \mu \mathrm{M}$ PK11195 or $10.0 \mu \mathrm{M}$ Ro5-4864, alone or in combination, or $600 \mu \mathrm{M}$ clonazepam.

\begin{tabular}{lllll}
\hline & Controls & PK & Ro & PK + Ro \\
\hline TUNEL (\%) & $14.3 \pm 6.6$ & $42.3 \pm 7.9^{*}$ & $11.1 \pm 4.1$ & $18.4 \pm 6.1$ \\
ELISA (OD) & $1.26 \pm 0.42$ & $2.16 \pm 0.57^{*}$ & $1.24 \pm 0.22$ & $12.3 \pm 4.5$ \\
\hline
\end{tabular}

Values of TUNEL and ELISA experiments differed significantly between groups $\left(P<0.01\right.$ by ANOVA); ${ }^{\star} P<0.05$ vs controls by the Bonferroni test. PK, PK11195; Ro, Ro5-4864; Clon, clonazepam.

a

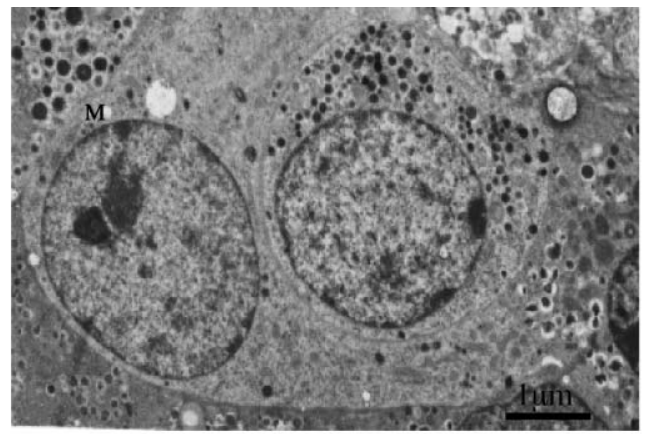

C

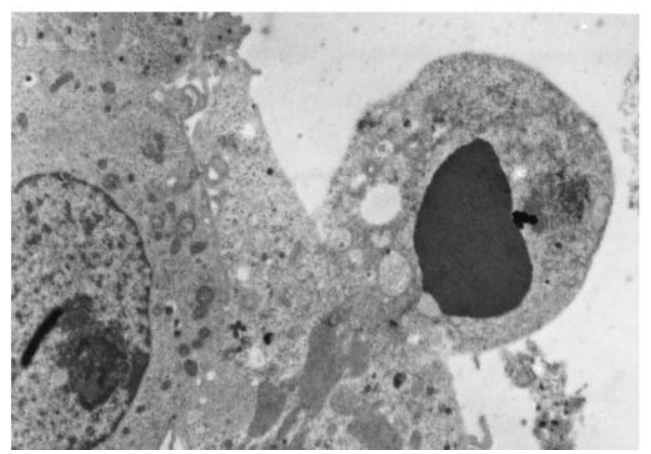

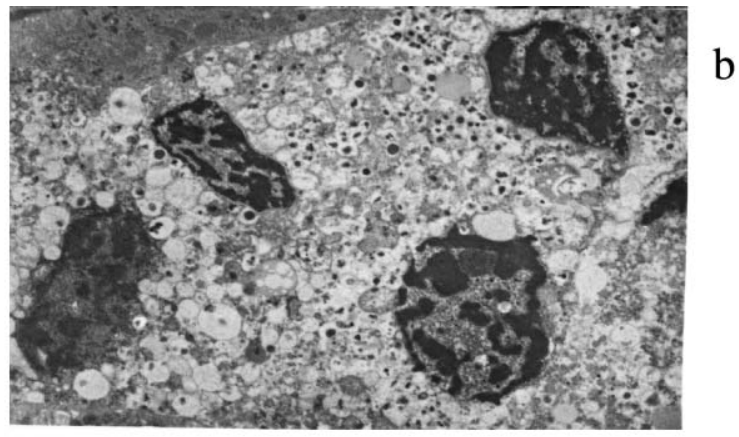

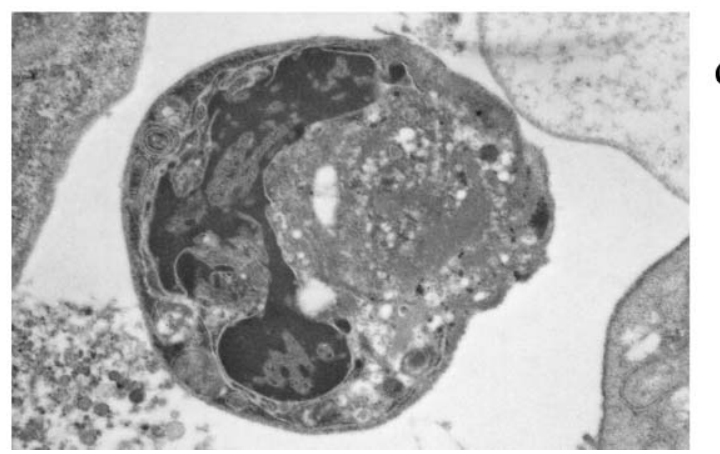

$b$

d
Figure 2 Electron microscopy of control human beta cells (a) and human beta cells after exposure to PK11195, showing chromatin condensation (b), membrane blebbing (c) and apoptotic bodies (d). 
O.D. (arbitrary units)

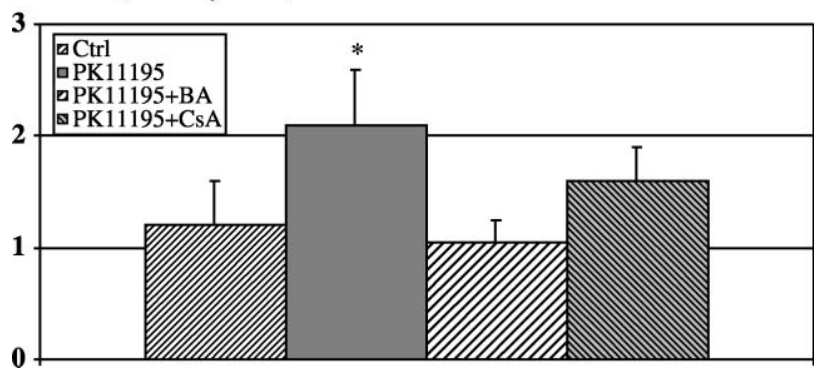

Figure 3 Cell death evaluated by an ELISA technique in control islets (Ctrl), islets exposed to $1.0 \mu \mathrm{mol} / \mathrm{l} \mathrm{PK} 11195(\mathrm{PK}), 1.0 \mu \mathrm{mol} / \mathrm{l}$ PK11195 plus bongkrekic acid (BA), and $1.0 \mu \mathrm{mol} / \mathrm{I}$ PK11195 plus cyclosporin A (CsA). OD, optical density in arbitrary units. ${ }^{\star} P<0.05$ vs control and $\mathrm{BA}$.

O.D. (arbitrary units)

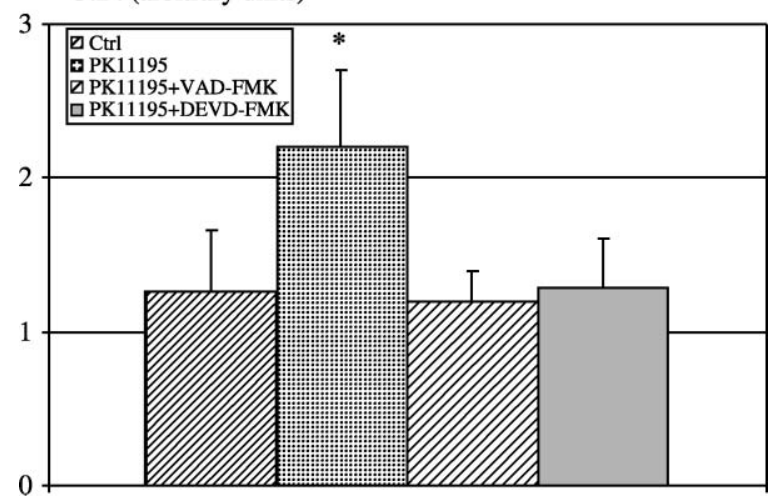

Figure 4 Cell death evaluated by an ELISA technique in control islets (Ctrl), islets exposed to $1.0 \mu \mathrm{mol} / \mathrm{l}$ PK11195 (PK), $1.0 \mu \mathrm{mol} / \mathrm{I} \mathrm{PK} 11195$ plus caspase inhibitor VAD-FMK, and $1.0 \mu \mathrm{mol} / \mathrm{I} \mathrm{PK} 11195$ plus caspase inhibitor DEVD-FMK. OD, optical density in arbitrary units. ${ }^{\star} P<0.05$ vs control, VAD-FMK and DEVD-FMK.

$0.18 \pm 0.03$ vs $0.11 \pm 0.02 ; n=5, P<0.05)$ was significantly higher after exposure to PK11195 than in control islets.

The role of the nitric oxide pathway was assessed by evaluating mRNA expression of iNOS and nitrite production. In addition, the expression of Bcl-2 and Bax mRNA was evaluated in control islets and islets pre-cultured for $12 \mathrm{~h}$ in the presence of PK11195. As shown in Fig. 5, mRNA expression of iNOS, Bcl-2 and Bax was similar in control and PK11195-incubated islets. When mRNA expression of these molecules was evaluated as the ratio over beta-actin mRNA expression in control islets and in islets exposed to PK11195, the following values were respectively found: for iNOS, $0.14 \pm 0.2$ and $0.17 \pm 0.2$; for Bcl-2, $0.72 \pm 0.06$ and $0.74 \pm 0.06$; for Bax, 0.38 \pm 0.06 and $0.42 \pm 0.07$. In accordance with iNOS mRNA expression data, no changes were found in the nitrite levels in the incubation media $(n=4$ each) of control $(0.9 \pm 0.1 \mu \mathrm{mol} / \mathrm{l})$ and PK11195 (1.0 $\pm 0.2 \mu \mathrm{mol} / \mathrm{l})-$ exposed islets.
Bcl-2

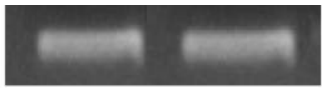

408bp

\section{Bax}

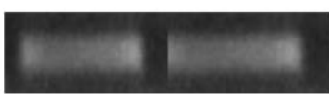

477bp

iNOS

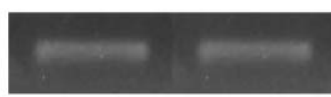

461bp

\section{$\beta$-actin}

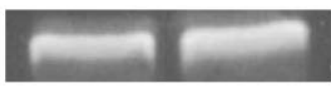

354bp

\section{Ctrl PK 1.0}

Figure 5 mRNA expression of Bcl-2, Bax and iNOS in control islets (Ctrl) and in islets pre-exposed to $1.0 \mu \mathrm{mol} / \mathrm{l} \mathrm{PK11195} \mathrm{(PK).}$

\section{Discussion}

The results of the present study show that prolonged and selective binding of peripheral benzodiazepine receptors, proteins located on the mitochondrial membrane, by the ligand PK11195 causes inhibition of glucose-stimulated insulin release and enhances apoptosis of human pancreatic islet cells. These effects were not evoked by incubation with either Ro5-4864 or clonazepam. In addition, we observed that Ro54864 was able to prevent the pro-apoptotic, but not the cytostatic, action of PK11195. The use of mitochondrial membrane transition stabilizing agents reduced the pro-apoptotic action of PK11195, demonstrating a crucial role of the permeability transition pore in these events. The pro-apoptotic effects of PK11195 were mediated by the action of caspases, did not involve the iNOS pathway, and were accompanied by no apparent change in the expression of Bax and Bcl2.

Our results on insulin secretion are in agreement with a cytostatic effect of PK11195 reported in rodent islets (27), and with the inhibition of glucose-mediated insulin release associated with the incubation of rat islets with diazepam binding inhibitor (DBI), a putative endogenous PBR ligand (28). The mechanism(s) through which PK11195 exerts its inhibitory effect on insulin release was in part explored in the present study, and we showed that the cytostatic action was not due to grossly altered transcription of insulin or glucose-transporter GLUT-1 from the coding genes. Rather, as suggested by a previous work with rodent islets (27), and as shown in the present study, PK11195 causes a reduction in oxidative glucose metabolism, which, in turn, leads to reduced insulin release.

PK11195 has been shown to induce apoptosis in several cell systems, such as hemopoietic cell lines $(8-10)$. However, this is the first demonstration that it also exerts a similar effect in a human primary cell model, and, in particular, in human islet beta-cells. 
It was of interest to find that Ro5-4864 exerts a protective effect upon the apoptotic stimulus triggered by PK11195, confirming previous observations obtained with cell lines (12). This effect was tentatively explained on the basis of a competition mechanism with Ro5-4864 displacing PK11195 from its binding sites (12).

The present study clearly demonstrates that caspases are involved in PK11195-induced islet cell apoptosis, as shown by the use of caspases inhibitors and the measurement of caspase- 3 and -9 activity. Caspase-3 is an effector protease that is activated by initiator caspases such as caspase-8, -9 and -10. These latter (upstream caspases) can be activated by cell membrane signaling (caspase-8 and -10) or mitochondrial-derived events (caspase-9) (29). Since PBRs are mainly located on the mitochondrial membrane (1), and they take part in the formation of mitochondrial transition pore (1), one might speculate that, as happens in other cell systems (8), direct ligand to PBRs alters the permeability of the mitochondrial membrane, leading to the release of effector caspases activators. In this regard, the release of molecules such as cytochrome $\mathrm{C}$ and apoptotic protease activating factor-1 (Apaf-1) has been well documented (30). These compounds bind to and activate pro-caspase-9, to form the so-called apoptosome (30), a potent activator of caspase- 3. Additional mitochondrial factors, however, can be released following mitochondrial membrane activation, that are known to induce or facilitate apoptotic death (31).

We also determined iNOS mRNA expression and nitrite concentration, since a number of pro-apoptotic conditions cause cell death via the activation of nitric oxide pathway (32). iNOS transcription generates nitric oxide from L-arginine, which, together with other compounds, can exert a toxic effect on islet cells by inhibiting iron-dependent enzymes, thereby impairing cellular mitochondrial function and DNA synthesis (32). This, however, seems to be an unlikely pathway to be activated by PK11195 in our system, since neither the expression of iNOS mRNA nor the nitrite concentration in the culture media were significantly affected in our experiments.

Moreover, we could not observe any change in the expression of Bcl-2 and Bax mRNA in PK11195exposed islets. Bcl-2 and Bax are protein members of the growing family of apoptosis-regulator gene products which may either promote cell survival (Bcl-2, Bcl-XL, Bcl-w and others) or encourage cell demise (Bax, Bak, Bad and others) (33). The relative amount of death agonists and antagonists from the Bcl-2 family is a regulatory rheostat which functions by selective protein-to-protein interaction. Bcl-2 and its homologs insert into intracellular membranes including mitochondria, and regulate mitochondrial changes preceding the activation of apoptogenic proteases and nucleases. In particular, Bcl-2 prevents all the early steps of apoptosis, such as disruption of the inner mitochondrial transmembrane potential and release of apoptogenic protease activators $(33,34)$. From our study it seems that binding of PK11195 can activate beta-cell apoptosis downstream and independently of the interaction of $\mathrm{Bcl}-2$ on the mitochondrial membrane. With regard to this, it has been demonstrated that once mitochondrial apoptotic pathways are activated, the protective effect of $\mathrm{Bcl}-2$ can be overridden, and the cell can commence the degradation phase in any way (35). Moreover, in blood cell lines it has been shown that PK11195 can reverse the protection induced by Bcl-2 (8-10).

A number of endogenous PBR ligands have been described. Protoporphyrin IX (PIX) binds to PBRs and it is thought that during heme biosynthesis, cytosolic coproporphyrinogen III traverses the mitochondrial membrane to be converted via protoporphyrin IX to heme (3). Additional candidates for endogenous ligands are the neuropeptide DBI (3) and a $16 \mathrm{kDa}$ protein called anthralin (3). Moreover, a recently described molecule, peripheral benzodiazepine receptor-associated protein (PRAX)-1, has been reported to have several domains involved in protein-protein interaction at the PBR level (36). Whereas the possible direct effects of PIX, anthralin and PRAX-1 on islet cells has not been tested, DBI has been shown to inhibit insulin release (28). More recently, upon construction of a human pancreatic islet cDNA library, screening of sera from diabetic patients led to the observation that one of the generated clones was strongly related to DBI (37). Lately, we have shown that cytotoxic cytokines, which are involved in the destruction of islet beta-cells in autoimmune diabetes, can increase the density of peripheral benzodiazepine receptors in human pancreatic islets as well as the expression of their mRNA (13). Now, the results of the present study clearly show that prolonged exposure of PBRs to the specific ligand PK-11195 has cytostatic and pro-apoptotic effects on human pancreatic islet cells. Thus, all together, available evidence supports the view that peripheral benzodiazepine receptors are involved in both secretory function and mass balance in human pancreatic beta cells.

\section{Acknowledgements}

This work was supported in part by grants from the Italian Ministero dell'Università e Ricerca Scientifica e Tecnologica (COFIN 1999 and COFIN 2000), by the Juvenile Diabetes Research Foundation (1-1999-679) and the Telethon Foundation (E660).

\section{References}

1 Casellas P, Galiegue S \& Basile AS. Peripheral benzodiazepine receptors and mitochondrial function. Neurochemistry International $2002 \mathbf{4 0} 475-486$. 
2 Kroemer G, Dallaporta B \& Resche-Rigon M. The mitochondrial death/life regulator in apoptosis and necrosis. Annual Review of Physiology $199860619-642$.

3 Szewczyk A \& Wojtczak L. Mitochondria as a pharmacological target. Pharmacological Review 200254 101-127.

4 Versijpt J, Dumont F, Thierens H, Jansen H, De Vos F, Slegers G et al. Biodistribution and dosimetry of [123I]iodo-PK 11195: a potential agent for SPET imaging of the peripheral benzodiazepine receptor. European Journal of Nuclear Medicine $2000 \quad 27$ $1326-1333$.

5 Gavish M, Bachman I, Shoukrun R, Katz Y, Veenman L, Weisinger $\mathrm{G}$ et al. Enigma of the peripheral benzodiazepine receptor. Pharmacological Review 199951 629-650.

6 Giusti L, Marchetti P, Trincavelli L, Lupi R, Martini C, Lucacchini A et al. Peripheral benzodiazepine receptors in isolated human pancreatic islets. Journal of Cellular Biochemistry $1997 \mathbf{6 4}$ 273-277.

7 Chelli B, Falleni A, Salvetti F, Gremigni V, Lucacchini A \& Martini C. Peripheral type benzodiazepine receptors ligands: mitochondrial permeability transition induction in rat cardiac tissue. Biochemical Pharmacology 200161 695-705.

8 Hirsch T, Decaudin D, Susin SA, Marchetti P, Larochette N, Resche-Rigon M et al. PK11195, a ligand of the mitochondria benzodiazepine receptor, facilitates the induction of apoptosis and reverses Bcl-2-mediated cytoprotection. Experimental Cell Research $1998241426-434$

9 Larochette N, Decaudin D, Jacotot E, Brenner C, Marzo I, Susin SA et al. Arsenite induces apoptosis via a direct effect on the mitochondrial permeability transition pore. Experimental Cell Research $1999249413-421$.

10 Ravagnan L, Marzo I, Costantini P, Susin SA, Zamzami N, Petit PX et al. Lonidamine triggers apoptosis via a direct. Bcl-2-inhibited effect on the mitochondrial permeability transition pore. Oncogene $1999182537-2546$

11 Dallaporta B, Marchetti P, de Pablo MA, Maisse C, Duc HT, Métivier D et al. Plasma membrane potential in thymocyte apoptosis. Journal of Immunology $1999 \mathbf{1 6 2} 6534-6542$.

12 Bono F, Lamarche I, Prabonnaud V, Le Fur G \& Herbert JM. Peripheral benzodiazepine receptor agonists exhibit potent antiapoptotic activities. Biochemical and Biophysical Research Communications $1999 \mathbf{2 6 5} 457-461$.

13 Trincavelli ML, Marselli L, Falleni A, Gremigni V, Ragge E, Dotta F et al. Upregulation of mitochondrial peripheral benzodiazepine receptor expression by cytokine-induced damage of human pancreatic islets. Journal of Cellular Biochemistry $2002 \mathbf{8 4}$ 636-644.

14 Marchetti P, Dotta F, Ling Z, Lupi R, Del Guerra S, Santangelo C et al. The function of pancreatic islets isolated from Type 1 diabetic patients. Diabetes Care 200023 701-703.

15 Parola AL, Yamamura HI \& Laird II HE. Peripheral-type benzodiazepine receptors. Life Science 199352 1329-1342.

16 Rosati B, Marchetti P \& Crociani O. Glucose and arginine-induced insulin secretion by human pancreatic beta-cells: the role of HERG $\mathrm{K}+$ channels in firing and release insulin release of human pancreatic beta-cells. FASEB Journal $2000 \quad \mathbf{1 4}$ 2601-2610.

17 Lupi R, Del Guerra S, Fierabracci V, Marselli L, Novelli M, Patanè G et al. Lipotoxicity in human pancreatic islets and the protective effect of metformin. Diabetes 200251 (Suppl 1) S134-S137.

18 Marselli L, Dotta F, Piro S, Santangelo C, Masini M, Lupi R et al. Th2 cytokines have a partial, direct protective effect on the function and survival of isolated human islets exposed to combined pro-inflammatory and Th1 cytokines. Journal of Clinical Endocrinology and Metabolism 200186 4974-4978.
19 Hortelano S, Dallaporta B, Zamzami N, Hirsch T, Susin SA, Marzo I et al. Nitric oxide induces apoptosis via triggering mitochondrial permeability transition. FEBS Letters $1997 \mathbf{4 1 0}$ $373-377$

20 Kidd VJ. Proteolytic activities that mediate apoptosis. Annual Reviews of Physiology $1998 \mathbf{6 0} 533-573$.

21 Ekert PG, Silke J \& Vaux DL. Caspase inhibitors. Cell Death and Differentiation $199961081-1086$.

22 Fadeel B, Hassan Z, Hellstrom-Lindberg E, Henter J-I, Orrenius S \& Zhivotovsky B. Cleavage of Bcl-2 is an early event in chemotherapy-induced apoptosis of human myeloid leukemia cells. Leukemia $199913719-728$

23 Piro S, Lupi R, Dotta F, Patané G, Rabuazzo MA, Marselli L et al. Bovine islets are less susceptible than human islets to damage by human cytokines. Transplantation 200171 21-26.

24 Assady S, Maor G, Amit M, Itskovitz-Eldor J, Skorecki KL \& Tzukerman M. Insulin production by human embryonic stem cells. Diabetes $2001501691-1697$.

25 Schroppel B, Fischereder M, Wiese P, Segerer S, Huber S, Kretzler $\mathrm{M}$ et al. Expression of glucose transporters in human peritoneal mesothelial cells. Kidney International 199853 1278-1287.

26 Cory S \& Adams JM. The Bcl 2 family: regulators of the cellular life-or-death switch. Nature Reviews Cancer 20022 647-656.

27 Pujalte D, Claeysen S, Dietz S, Chapal J, Hillaire-Buys D \& Petit P. Inhibition of glucose-induced insulin secretion by a peripheraltype benzodiazepine receptor ligand (PK11195). Naunyn-Schmiedeberg's Archives of Pharmacology 2000362 46-51.

28 Borboni P, Condorelli L, De Stefanis P, Sesti G \& Lauro R. Modulation of insulin secretion by diazepam binding inhibitor and its processing products. Neuropharmacology $1991301399-1403$.

29 Earnshaw WC, Martins LM \& Kaufmann SH. Mammalian caspases: structure, activation, substrates, and functions during apoptosis. Annual Review of Biochemistry $199968383-424$

30 Budihardjo I, Oliver H, Lutter M, Luo X \& Wang X. Biochemical pathways of caspase activation during apoptosis. Annual Review of Cell and Developmental Biology 199915 269-290.

31 Hunot S \& Flavell RA. Death of a monopoly? Science 2001292 $865-866$.

32 Delaney CA, Pavlovic D, Hoorens A, Pipeleers DG \& Eizirik DL. Cytokines induce deoxyribonucleic acid strand breaks and apoptosis in human pancreatic islet cells. Endocrinology $1997 \mathbf{1 3 8}$ 2610-2614.

33 Reed JC, Jurgensmeier JM \& Matsuyama S. Bcl-2 family proteins and mitochondria. Biochimica et Biophysica Acta 19981366 $127-137$.

34 Adams JM \& Cory S. The Bcl-2 protein family: arbiters of cell survival. Science $1998 \mathbf{2 8 1} 1322-1326$.

35 Zamzami N, Brenner C, Marzo I, Susin SA \& Kroemer G. Subcellular and submitochondrial mode of action of Bcl-2-like oncoproteins. Oncogene $1998162265-2282$.

36 Galiegue S, Jbilo O, Combes T, Bribes E, Carayon P, Le Fur G \& Casellas P. Cloning and characterization of PRAX-1. A new protein that specifically interacts with the peripheral benzodiazepine receptor. Journal of Biological Chemistry 1999274 2938-2952.

37 Suk K, Kim YH, Hwang DY, Ihm SH, Yoo HJ \& Lee MS. Molecular cloning and expression of a novel human cDNA related to the diazepam binding inhibitor. Biochimica et Biophysica Acta $1999 \mathbf{1 4 5 4}$ $126-131$

Received 24 October 2003

Accepted 14 April 2004 